\title{
Complete mitochondrial genome sequence of the humphead wrasse, Cheilinus undulatus
}

\author{
X.Z. Qi ${ }^{1,2}$, S.W. Yin ${ }^{3}$, J. Luo ${ }^{2}$ and R. Huo ${ }^{2}$ \\ ${ }^{1}$ Key Laboratory of Tropic Biological Resources, Hainan University, \\ Haikou, China \\ ${ }^{2}$ Central Lab of Marine Biology of the Ocean College, \\ Hainan University, Haikou, China \\ ${ }^{3}$ College of Life Sciences, Nanjing Normal University, Nanjing, China \\ Corresponding author: S.W. Yin \\ E-mail: yinshaowu@163.com
}

Genet. Mol. Res. 12 (2): 1095-1105 (2013)

Received June 26, 2012

Accepted September 10, 2012

Published April 10, 2013

DOI http://dx.doi.org/10.4238/2013.April.10.5

\begin{abstract}
The humphead wrasse (Cheilinus undulatus) is a large coral fish that has become threatened due to habitat loss and fishing pressure. We sequenced the mitochondrial genome of $C$. undulatus, using a normal PCR method. The complete mtDNA sequence encoded 13 protein genes, 22 tRNA genes and 2 rRNA genes. It was found to be 16,613 bp in length and had an overall $\mathrm{H}$-strand base compositions of 27.3 for A, 30.9 for C, 16.8 for G, and $25.0 \%$ for T. Compared with the sequences of 8 other members of the family Labridae, gene content, genome organization, and nucleotide compositions were similar. All tRNAs formed a typical clover-leaf structure, except $t R N A^{\text {Ser }}$ (AGY), and most of the size variations among tRNAs stemmed from variations

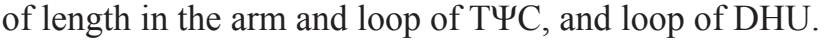

Key words: Mitochondrial genome; Cheilinus undulatus; Normal PCR method 


\section{INTRODUCTION}

The humphead wrasse (Cheilinus undulatus) is a large coral reef fish that is widely distributed in the tropical Indo-Pacific region, and it is the largest living member of the family Labridae, with a maximum size exceeding $2 \mathrm{~m}$ and $190 \mathrm{~kg}$ (Sadovy et al., 2003). The humphead wrasse is the most valuable fish in the live reef food fish trade in Asia. It is particularly susceptible to overexploitation due to its life history, which involves slow growth, late sexual maturity, longevity, sex reversal, and low replenishment rates (Sadovy, 2002).

In 1996, the humphead wrasse was listed as a vulnerable species in the International Union for Conservation of Nature Red List, the first to focus on the status of marine fishes specifically. It was listed due to the concerns of rapidly declining populations in many areas during the last decade (Sadovy and Vincent, 2002). Therefore, it is important to evaluate the genetic diversity of the humphead wrasse for the conservation of its germplasm resource.

Mitochondrial DNA (mtDNA), with the characteristics of maternal inheritance, compact size, multiple copies per cell, rapid evolutionary rate, and rare recombination, has been widely used as a source of molecular markers to analyze populations and the evolution of fishes (Craig et al., 2001; Maggio et al., 2005; Ding et al., 2006). Most of these markers such as cytochrome b, 12S ribosomal RNA, cytochrome c oxidase subunit I, and NADH dehydrogenase subunit 2 are identified in a few mitochondrial regions, and adequate resolution of evolutionary relationships requires longer DNA sequence (Miya and Nishida, 2000). Thus, entire mitochondrial genome sequences containing more information are required to construct phylogenetic trees, rather than the simple collection of individual gene sequence. The examination of mitochondrial genomes may reveal important genome-level characteristics, such as length variation, base compositional bias, codon usage, gene rearrangement, RNA secondary structures, and control modes of replication and transcription (Sheffield et al., 2008).

In the present study, we amplified the mitochondrial genome of $C$. undulatus using a normal polymerase chain reaction (PCR) method and described its gene organization and control region. Complete mtDNA sequence data would provide important information not only for population studies of $C$. undulatus, but also for phylogenetic studies of the genus Cheilinus.

\section{MATERIAL AND METHODS}

\section{Fish samples and DNA extraction}

The C. undulatus specimen was obtained from Qing Li Fisheries Company of Sanya, and the harvested tissues for DNA extraction were immediately frozen at $-80^{\circ} \mathrm{C}$. Total genomic DNA was extracted from dorsal muscle tissues by the following procedure. Approximately 0.1 $\mathrm{g}$ tissue was homogenized in $1 \mathrm{~mL}$ digestion buffer $(10 \mathrm{mM}$ Tris-HCl, $\mathrm{pH}$ 8.0, $2 \mathrm{mM}$ EDTA, $10 \mathrm{mM} \mathrm{NaCl}, 1 \%$ sodium dodecyl sulfate, $10 \mathrm{mg} / \mathrm{mL}$ dithiothreitol, $0.5 \mathrm{mg} / \mathrm{mL}$ proteinase $\mathrm{K}$ ) and incubated at $37^{\circ} \mathrm{C}$ for $8-16 \mathrm{~h}$, followed by standard phenol-chloroform extraction. The DNA samples were stored in $50 \mu \mathrm{L}$ TE buffer.

\section{Amplification, cloning and sequencing of PCR products}

A series of primers based on the complete mitochondrial genome sequence of Hali- 
choeres melanurus (GenBank accession No. NC009066) were designed (Table 1). PCR was carried out using a Mastercycler gradient (Eppendorf) with a $25-\mu \mathrm{L}$ reaction mixture containing $50 \mathrm{ng}$ total genomic DNA, $0.2 \mathrm{mM}$ dNTPs, $0.2 \mu \mathrm{M}$ of each primer, $2.5 \mu \mathrm{L} 10 \mathrm{X}$ ExTaq reaction buffer, and $2 \mathrm{U}$ ExTaq polymerase (TaKaRa). The PCR parameters were set up as initial denaturation at $94^{\circ} \mathrm{C}$ for $4 \mathrm{~min}$, followed by 30 cycles composed of DNA denaturation at $94^{\circ} \mathrm{C}$ for $30 \mathrm{~s}$, annealing at $47-53^{\circ} \mathrm{C}$ for $30 \mathrm{~s}$ and extension at $72^{\circ} \mathrm{C}$ for $2 \mathrm{~min}$, and a final extension at $72^{\circ} \mathrm{C}$ for $7 \mathrm{~min}$. The amplified PCR products were purified and ligated into pMD18-T vector (TaKaRa). The sequences of resultant plasmids were verified at Shanghai Bio-Engineering Technology Co., Ltd.

\section{Data analysis}

The sequence of each identified gene was compared with the mitochondrial genome sequence of $H$. melanurus. To comparatively analyze the control region of mitochondrial genomes, 6 complete mitochondrial genome sequences of Labridae were collected from GenBank. Homologous sequences for each gene are initially aligned using ClustalX (Thompson et al., 1997), and further analysis was carried out by MEGA version 4.0 (Tamura et al., 2007).

\section{RESULTS}

\section{Primer design strategy}

The normal PCR method included template selection, PCR primer design, PCR amplification, and sequence splicing. Parajulis poecilepterus, H. melanurus and Pseudolabrus sieboldi are important members of the family Labridae. The complete mitochondrial genome sequences of three species and four mitochondrial gene sequences of $C$. undulatus from GenBank [EF609322 (COI), EU601399 (Cyt b), EU601220 (tRNA-Phe and 12S), and AY279685 (16S)] were downloaded. After sequences of three complete mitochondrial genomes and four mitochondrial genes were subjected to alignment analysis by the NCBI BLAST software, the complete mitochondrial genome sequence of $H$. melanurus was selected as the template for the design of PCR primers.

The design strategies and criteria of PCR primers are shown in Figure 1. 1) The length of PCR products was controlled in the range of $1300-1500 \mathrm{bp}$ for the following reasons: a) the reaction can only analyze the sequence in the range of 800-1000 bp using current DNA sequencing technology; b) adjacent amplified fragments must have some overlap for facilitating splicing; c) research cost should be low. 2) We designed primers for two rounds of PCR. The primer pairs in each round had half the total number of primer pairs and the distance between fragments amplified by adjacent primer pairs was approximately 1000-1200 bp, as shown in Figure 1A. 3) Sequence alignment analysis was conducted by the BLAST software for the sequencing results of the firstround PCR products and the PCR primer template. The first-round PCR products were used to replace the corresponding parts of the template sequence. 4) The new sequence generated from the first round PCR products was used as the template for the design of the second-round PCR primers. Moreover, during the primer design for the second-round PCR, each primer pair must be included in the new sequence to ensure some overlap between the second-round PCR products and the new sequence in the template (Figure 1B). 5) For the primers with low efficiency, we also developed a new primer pair outside the original primer that did not work for nested PCR amplification (Figure 
1C). Totally, 12 primer pairs were designed for the first-round PCR, as shown in Table 1. Agarose gel electrophoresis of the first-round PCR products showed that 3 primer pairs (Sumei-A4sen and Sumei-A4ant; Sumei-A6sen and Sumei-A6ant; Sumei-A7sen and Sumei-A7ant) were of low efficiency and could not complete PCR. Therefore, we designed 3 new primer pairs (Sumei-A4-2sen and Sumei-A4-2ant; Sumei-A6-2sen and Sumei-A6-2ant; Sumei-A7-2sen and Sumei-A7-2ant) outside the original primers for nested PCR amplification, as shown in Table 2. The sequence alignments between the sequencing results of the first-round PCR products and the template of PCR primers were conducted to replace the corresponding parts of the template sequence using the first-round PCR products. Based on the newly generated sequences as the template, 10 primer pairs were designed for the second-round PCR, as shown in Table 1.

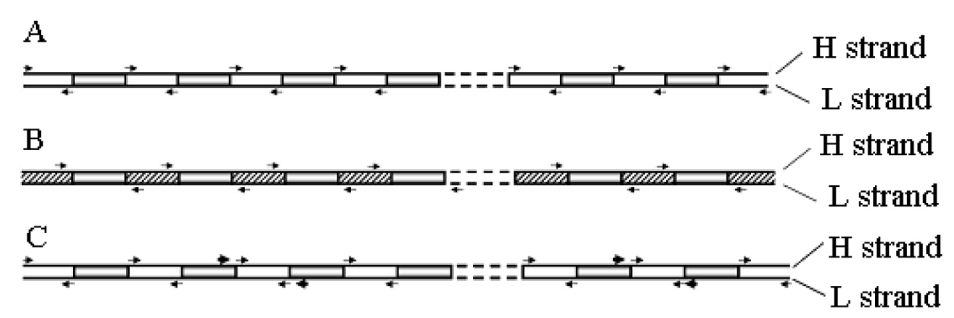

Figure 1. Design strategies of PCR primers. Two rounds of PCR primers were designed. A. The mtDNA genome sequence of Halichoeres melanurus was selected as the template for the first-round PCR primers, and the distance between fragments amplified by adjacent primer pairs was approximately 1000-1200 bp. B. The first-round PCR products were used to replace the corresponding parts of the mtDNA genome sequence of $H$. melanurus, and the new sequence was used as the template for the design of the second-round PCR primers. C. For the primers with low efficiency, a new primer pair outside the original primer was developed for nested PCR amplification.

Table 1. Primer pairs of the complete mitochondrial genome sequences of humphead wrasse.

\begin{tabular}{|c|c|c|c|}
\hline \multicolumn{2}{|c|}{ First-round PCR primers } & \multicolumn{2}{|c|}{ Second-round PCR primers } \\
\hline Primer name & Primer sequence $\left(5^{\prime}-3^{\prime}\right)$ & Primer name & Primer sequence $\left(5^{\prime}-3^{\prime}\right)$ \\
\hline Sumei-A1sen & ACCCTAGAAAGTTCCGAGAGC & Sumei-B1sen & ACCCTGAAGTCTACATCCTC \\
\hline Sumei-Alant & CTTCATTTCGGTTTTCAGCC & Sumei-B1ant & GGCTAAGTCTTGGGTAGG \\
\hline Sumei-A2sen & AGAGCACAAAGGCTTGGTCC & Sumei-B2sen & СТTCTCCCTCTTTCTCGTCCT \\
\hline Sumei-A2ant & CCTTCCCTTGCGGTACTTAAC & Sumei-B2ant & GCTCGGCTAGGTGGGTAAT \\
\hline Sumei-A3sen & СССССААСССТССТТТАСАА & Sumei-B3sen & TTCATTGACGCTCGCATAAG \\
\hline Sumei-A3ant & GACCAATGGCCATCATAGCTCA & Sumei-B3ant & TGTGCCTGATACCAGCTCCT \\
\hline Sumei-A4sen & ATGGTGGCAGAGCACGGCAA & Sumei-B4sen & CTCCGAAAGTCTCAACCCAC \\
\hline Sumei-A4ant & TCATGCAAGTAGCCAGTGGGAGC & Sumei-B4ant & TTATTCCGTAACGAAGGCCT \\
\hline Sumei-A5sen & СССТСАССТАACCATTAAAGCC & Sumei-B5sen & CTATCGCATTCGCAGGTCTC \\
\hline Sumei-A5ant & TGGAATCAGACAGCAAGGCC & Sumei-B5ant & GGCAGATGCTCGCTGGTTA \\
\hline Sumei-A6sen & CTAGCCCTCACAGGAATG & Sumei-B6sen & ATCAACGGACCAAGTTACCC \\
\hline Sumei-A6ant & GACGAAGGTGGTTATTGC & Sumei-B6ant & GAGGCGTGCCTTTAGCAG \\
\hline Sumei-A7sen & TAGCCATGCTTGCCTTAA & Sumei-B7sen & GGTAAGTGTACCGGAAGGTG \\
\hline Sumei-A7ant & CGTTGGCGTGTATGTTTC & Sumei-B7ant & GAGGAGGTTAGGACAGATTGAG \\
\hline Sumei-A8sen & ACTATGGTCGTAGCAGGGAT & Sumei-B8sen & GTACATCCCCTCATTACCCACCT \\
\hline Sumei-A8ant & ATGGTGAGCGGAGATGTT & Sumei-B8ant & GGGAGGGCATTCTCACGG \\
\hline Sumei-A9sen & CTCGCTCCGATTCTTCCT & Sumei-B9sen & CTTCCCGAACGAACCGACT \\
\hline Sumei-A9ant & GCCCGTTATGATTACACCTC & Sumei-B9ant & GAGGAGTACAGTGCCGAGGG \\
\hline Sumei-A10sen & GGGAGGCAAGTCGTAACAT & Sumei-B10sen & CAGGTCTCCCACCACAACTT \\
\hline Sumei-A10ant & TCCCCTTTAGATACACCAGTG & Sumei-B10ant & CCTGTCTAGGGAGGGCTTTA \\
\hline Sumei-A11sen & GAAACTTAACGGACCCAACA & & \\
\hline Sumei-A11ant & TGCTAAGGGATTCAGGATGT & & \\
\hline Sumei-A12sen & ACACCCACAGTTAGGTCAGC & & \\
\hline Sumei-A12ant & GGGAGGGCTTTAGCTTAATT & & \\
\hline
\end{tabular}


Table 2. Second-round PCR primer pairs for the complete mitochondrial genome sequences of humphead wrasse and the new primer pairs outside the low-efficiency primers.

\begin{tabular}{llc}
\hline Primer name & Primer sequence (5'-3') & Remarks \\
\hline Sumei-A4-2sen & GCACGGCAATTGCGAAAGG & The new primer pair outside the \\
Sumei-A4-2ant & GCCAAGGCCAATTAGAAGTGTGG & 4th primer that did not work for PCR \\
Sumei-A6-2sen & CATAACTCAGCGAGGACAAC & The new primer pair outside the \\
Sumei-A6-2ant & GACTGGTGTAGGGCCTTCT & 7th primer that did not work for PCR \\
Sumei-A7-2sen & AGACGCAATCATCGAATCAC & The new primer pair outside the \\
Sumei-A7-2ant & GTGGCAATGTCAGAGGTGTAG & 3rd primer that did not work for PCR \\
\hline
\end{tabular}

Besides the reduction of the experimental cost and technical difficulties, the normal PCR method can avoid the inherent complexities of long PCR techniques and result in amplified PCR products with the convenience of sequencing. Compared with conventional long PCR techniques, the normal PCR method can identify a series of technical parameters and form a new method for amplifying mtDNA. For example, two adjacent sections of PCR products should have approximately $100 \mathrm{bp}$ overlap. Because some regions are not conserved and since the primers located in those regions are of low efficiency, we designed the inlaid PCR primers for nested PCR amplification to ensure the success of the experiments.

\section{General features of mitochondrial genome in $C$. undulatus}

The total length of the mitochondrial genome in C. undulatus was $16,613 \mathrm{bp}$, and similar to that of other animal mitochondrial genomes (Boore, 1999). The organization and location of the mitochondrial genome of $C$. undulatus was in accordance with the pattern observed in other teleostean mtDNAs (Figure 2). This mitochondrial genome included 13 protein genes, 22 tRNA genes, and 2 rRNA genes. It also had an overall $\mathrm{H}$-strand base composition of $27.3 \mathrm{~A}, 30.9 \mathrm{C}, 16.8 \mathrm{G}$, and $25.0 \% \mathrm{~T}$. Meanwhile, the sequence of the control region (Dloop) located between tRNA-Pro and tRNA-Phe was 903 bp in size, comprising 5.44\% of the whole genome. The complete mitochondrial genome sequence of $C$. undulatus was deposited in GenBank with the accession No. GU296101.

\section{DISCUSSION}

\section{Protein-coding genes}

The mtDNA of $C$. undulatus encoded 13 protein genes. Among these 13 protein genes, ND1, ATP8, ND5, and ND6 use ATG as the start codon and TAA as the stop codon; ND2, ND3, ND4, ND4L, ATP6, COX2, COX3, and Cyt-b use ATG as the start codon, but do not possess proper stop codons although a terminal T or TA where the TAA appears is created via post-transcriptional polyadenylation (Ojala et al., 1981). The exception is only COX1 with GTG as the start codon and AGG as the stop codon. The gene pairs of ATP8-ATP6, COX1-tRNA $A^{\text {Ser }}$ and ND5ND6 exhibited overlap lengths of 9, 8 and 3 bp, respectively. Eight tRNA genes ( $t R N A^{G l n}, t R N A^{A l a}$, $t R N A^{A s n}, t R N A^{C y s}, t R N A^{T y r}, t R N A^{S e r}, t R N A^{G l u}$, and $t R N A^{P r o}$ ) and one protein gene (ND6) were located on the light strand. The direction, location, and encoding-strand selection of the genes from C. undulatus were identical to those of the typical bony fishes (Figure 2 and Table 3). 


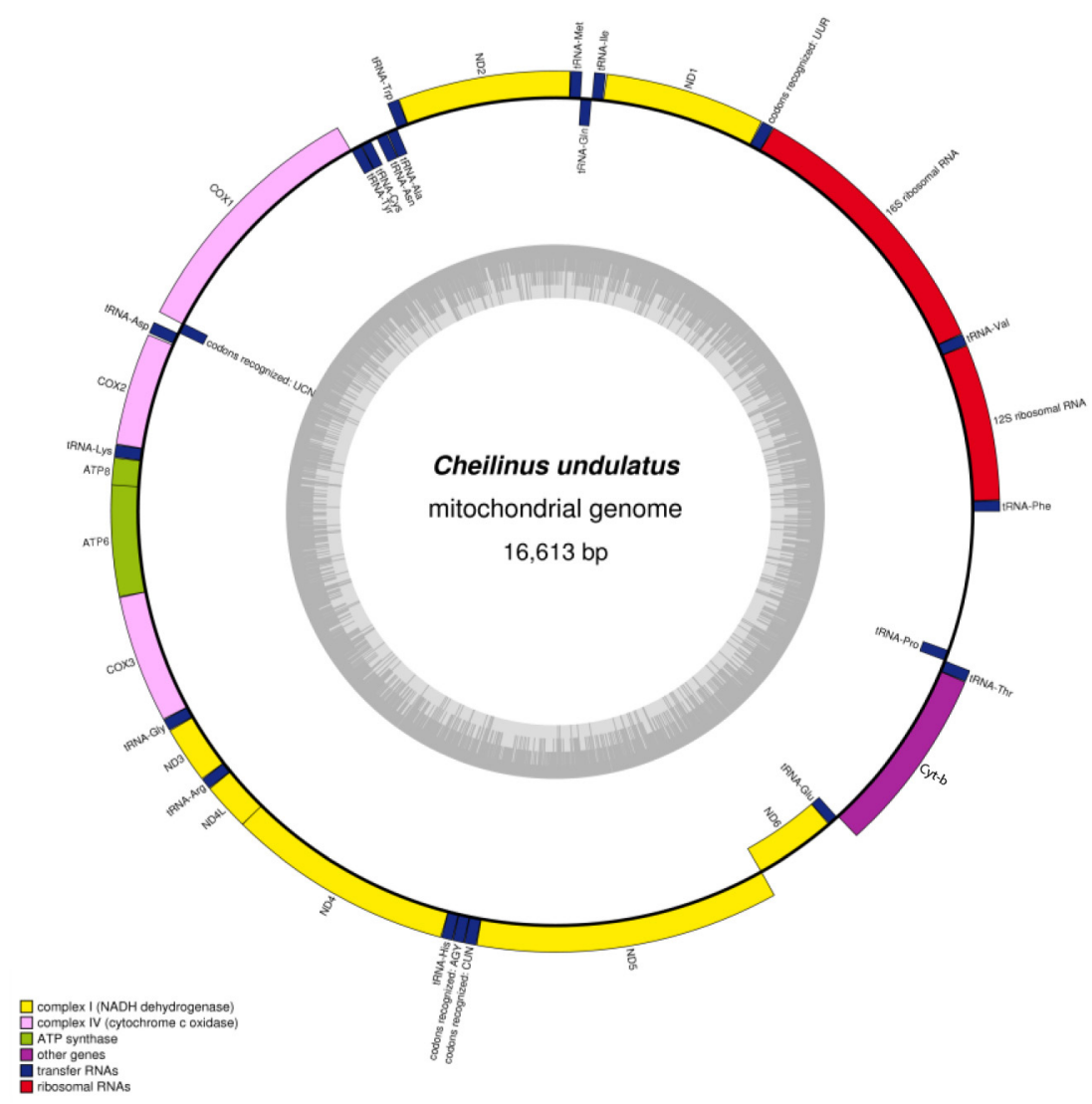

Figure 2. Structure of the mitochondrial genome and annotation of protein-coding genes from Cheilinus undulatus. $\mathrm{ND} 1$ = NADH dehydrogenase subunit 1 gene; ND2 = NADH dehydrogenase subunit 2 gene; ND3 = NADH dehydrogenase subunit 3 gene; ND4L = NADH dehydrogenase subunit 4L gene; ND4 = NADH dehydrogenase subunit 4 gene; ND5 = NADH dehydrogenase subunit 5 gene; ND6 = NADH dehydrogenase subunit 6 gene; COX1 $=$ cytochrome $\mathrm{C}$ oxidase subunit 1 gene; $\mathrm{COX} 2=$ cytochrome $\mathrm{C}$ oxidase subunit 2 gene; $\mathrm{COX} 3=$ cytochrome $\mathrm{C}$ oxidase subunit 3 gene; ATP8 = ATP synthase F0 subunit 8 gene; ATP6 = ATP synthase F0 subunit 6 gene; Cyt-b = cytochrome B gene; small spacer regions $=$ D-loop region.

\section{RNA genes}

The mitochondrial genome of $C$. undulatus contained 22 tRNA genes interspersed between the rRNA and protein-coding genes. The lengths of the 22 tRNA genes ranged from 68 to $77 \mathrm{bp}$. The predicted secondary structures of tRNAs are shown in Figure 3. Most of the

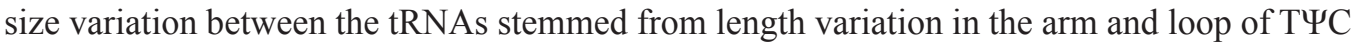
and loop of DHU.

All tRNAs could form a typical clover-leaf structure except for $t R N A^{\text {Ser }}$ (AGY) (Figure 3), and all putative secondary clover-leaf structures contained $7 \mathrm{bp}$ in the amino acid acceptor (AA) stem, while the majority had 5 or $4 \mathrm{bp}$ in the T $\psi \mathrm{C}$ stem, 5 or $4 \mathrm{bp}$ in the anticodon stem, and 4 or $3 \mathrm{bp}$ in the DHU stem. 


\begin{tabular}{|c|c|c|c|c|c|c|c|c|c|}
\hline Gene/control region & Position & Size (bp) & AA & Strand & Gene/control region & Position & Size (bp) & AA & Strand \\
\hline tRNA-Phe & $1-68$ & 68 & & $\mathrm{H}$ & $t R N A^{L y s}$ & $7903-7979$ & 77 & & $\mathrm{H}$ \\
\hline rRNA12sr & 69-1024 & 956 & & $\mathrm{H}$ & ATP8 gene & $7981-8148$ & 168 & 55 & $\mathrm{H}$ \\
\hline tRNA-Val & $1025-1096$ & 72 & & $\mathrm{H}$ & ATP6 gene & $8139-8821$ & 683 & 227 & $\mathrm{H}$ \\
\hline rRNA16sr & $1097-2798$ & 1702 & & $\mathrm{H}$ & $C O X 3$ gene & $8822-9606$ & 785 & 261 & $\mathrm{H}$ \\
\hline tRNA-Leu & $2799-2871$ & 73 & & $\mathrm{H}$ & $t R N A^{G l y}$ & $9607-9678$ & 72 & & $\mathrm{H}$ \\
\hline NDl gene & $2874-3848$ & 975 & 324 & $\mathrm{H}$ & ND3 gene & $9680-10031$ & 352 & 117 & $\mathrm{H}$ \\
\hline tRNA-Ile & $3853-3922$ & 70 & & $\mathrm{H}$ & $t R N A^{\text {Arg }}$ & $10032-10100$ & 69 & & $\mathrm{H}$ \\
\hline tRNA-Gln & 3924-3994 & 71 & & $\mathrm{~L}$ & $N D 4 L$ gene & 10101-10396 & 296 & 98 & $\mathrm{H}$ \\
\hline tRNA-Met & $3994-4063$ & 70 & & $\mathrm{H}$ & $N D 4$ gene & $10391-11772$ & 1382 & 460 & $\mathrm{H}$ \\
\hline ND2 gene & $4064-5108$ & 1045 & 348 & $\mathrm{H}$ & $t R N A^{H i s}$ & $11773-11841$ & 69 & & $\mathrm{H}$ \\
\hline tRNA-Trp & $5109-5179$ & 71 & & $\mathrm{H}$ & $t R N A^{S e r}$ & $11842-11912$ & 71 & & $\mathrm{H}$ \\
\hline tRNA-Ala & $5182-5250$ & 69 & & $\mathrm{~L}$ & $t R N A^{\text {Leu }}$ & $11913-11985$ & 73 & & $\mathrm{H}$ \\
\hline tRNA-Asn & $5253-5325$ & 73 & & $\mathrm{~L}$ & ND5 gene & $11986-13824$ & 1839 & 612 & $\mathrm{H}$ \\
\hline tRNA-Cys & $5366-5433$ & 68 & & $\mathrm{~L}$ & ND6 gene & $13821-14351$ & 531 & 176 & $\mathrm{~L}$ \\
\hline tRNA-Tyr & $5434-5504$ & 71 & & $\mathrm{~L}$ & $t R N A^{G l u}$ & $14350-14420$ & 71 & & $\mathrm{~L}$ \\
\hline$C O X 1$ gene & $5506-7065$ & 1560 & 519 & $\mathrm{H}$ & $C y t-b$ gene & $14426-15566$ & 1141 & 380 & $\mathrm{H}$ \\
\hline tRNA-Ser & $7057-7127$ & 71 & & $\mathrm{~L}$ & $t R N A^{T h r}$ & $15567-15639$ & 73 & & $\mathrm{H}$ \\
\hline tRNA-Asp & $7131-7203$ & 73 & & $\mathrm{H}$ & $t R N A^{\text {Pro }}$ & $15639-15710$ & 72 & & $\mathrm{~L}$ \\
\hline$C O X 2$ gene & $7212-7902$ & 691 & 230 & $\mathrm{H}$ & D-loop & $15711-16613$ & 903 & & - \\
\hline
\end{tabular}

$\mathrm{H}=$ heavy strand; $\mathrm{L}=$ light strand.

The 12S rRNA and 16S rRNA genes were 956 and 1702 bp in length, respectively. As in other vertebrates, both genes are located between genes of $t R N A^{\text {Phe }}$ and $t R N A^{\operatorname{Leu}(U U R)}$, and separated by the $t R N A^{V a l}$ gene (Hou et al., 2007). The overall content of the bases was similar to that observed for other Labridae (data not shown).

\section{Control region}

In vertebrates, each mtDNA strand (heavy strand and light strand) has its own control region, which forms a stable stem-loop structure (Pereira, 2000). The major portion of mtDNA involved in transcription and replication of the heavy strand in vertebrates is called the D-loop region and has been well characterized (Shadel and Clayton, 1997; Sbisa et al., 1997). The vertebrate D-loop region typically located between $\operatorname{trn} P$ and $\operatorname{trn} F$ is divided into three major domains: extended termination-associated sequences (ETAS), central domain (CD), and conserved sequence block (CSB). Each of these domains carries particular conserved functional motifs (Bourlat et al., 2009).

However, in most bony fishes, the origin of light-strand replication $\left(\mathrm{O}_{\mathrm{L}}\right)$ in $C$. undulatus was between $t R N A^{A s n}$ and $t R N A^{C y s}$ and was 40 nucleotides in length. The region had the potential to fold into a typical stem-loop secondary structure with $11 \mathrm{bp}$ in the stem and $13 \mathrm{bp}$ in the loop (Figure 4A). As shown in Figure 4B, the $\mathrm{O}_{\mathrm{L}}$ for 7 species from the family Labridae was submitted to alignment analysis by ClustalX, and the results showed that the secondary structure of $\mathrm{O}_{\mathrm{L}}$ was composed of a conserved stem (CCCCCGCCT**/GGGGGCGGA**) and two-variable base (asterisks) loop structure.

Compared with the structure of the control region (D-loop) located between tRNAPro and tRNA-Phe in other fishes (Cao et al., 2007; Tang et al., 2009; Tan et al., 2010), the ETAS, CD and CSB were identified, as shown in Figure 5. The TAS domain was 300-320 bp in length and the ETAS (TACATTGCTTGCAGTATTACAT) was observed in this domain. Two conserved blocks (CSB-F and CSB-D) in CD and three CSB (CSB-1, CSB-2 and CSB-3) were also identified in the CSB domain (Figure 5). 

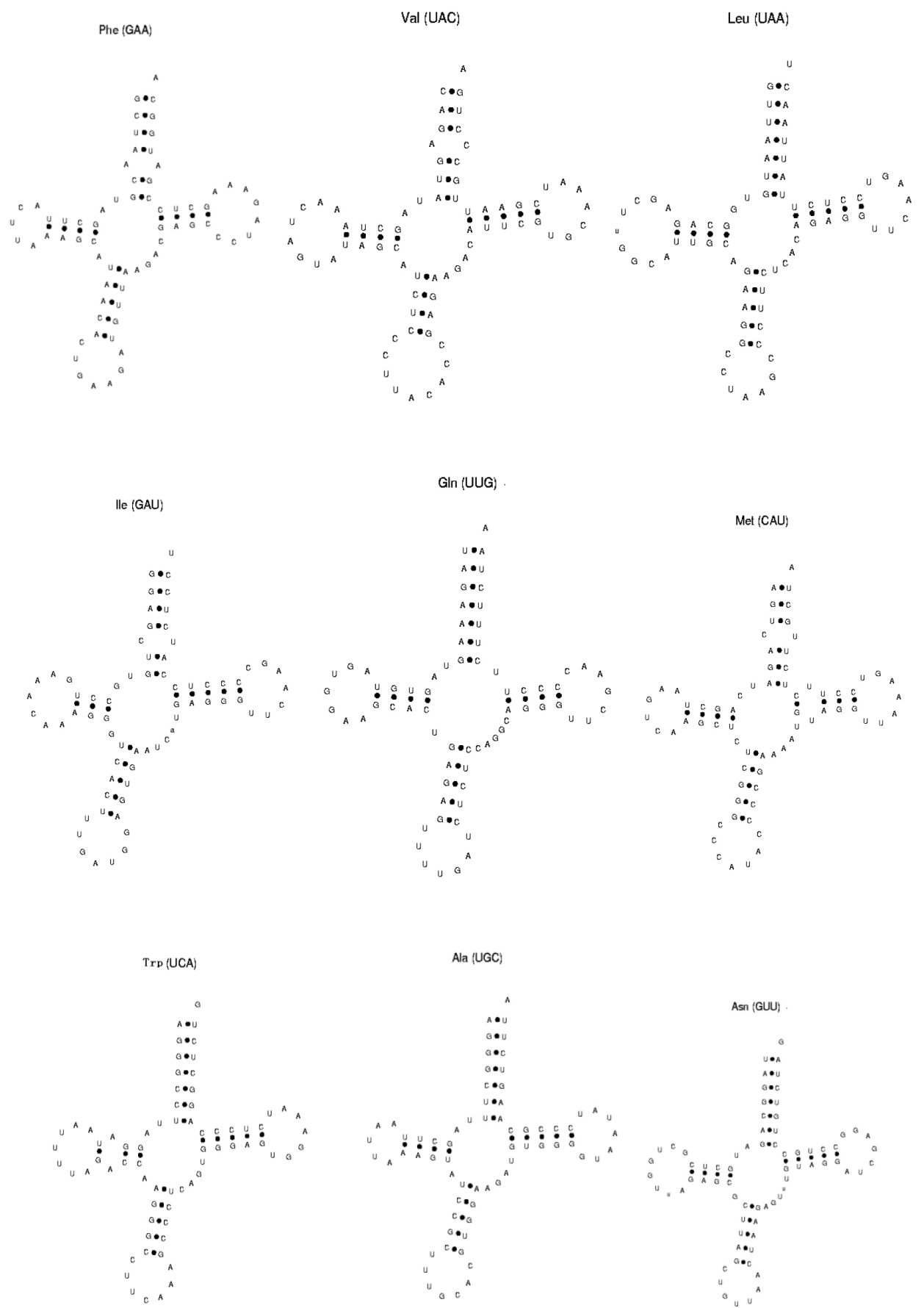

Figure 3. Inferred secondary structures of 21 tRNAs from mitochondrial genome of Cheilinus undulatus. The tRNAs are labeled with abbreviations of their corresponding amino acids.

Continued on next page 
Figure 3. Continued.
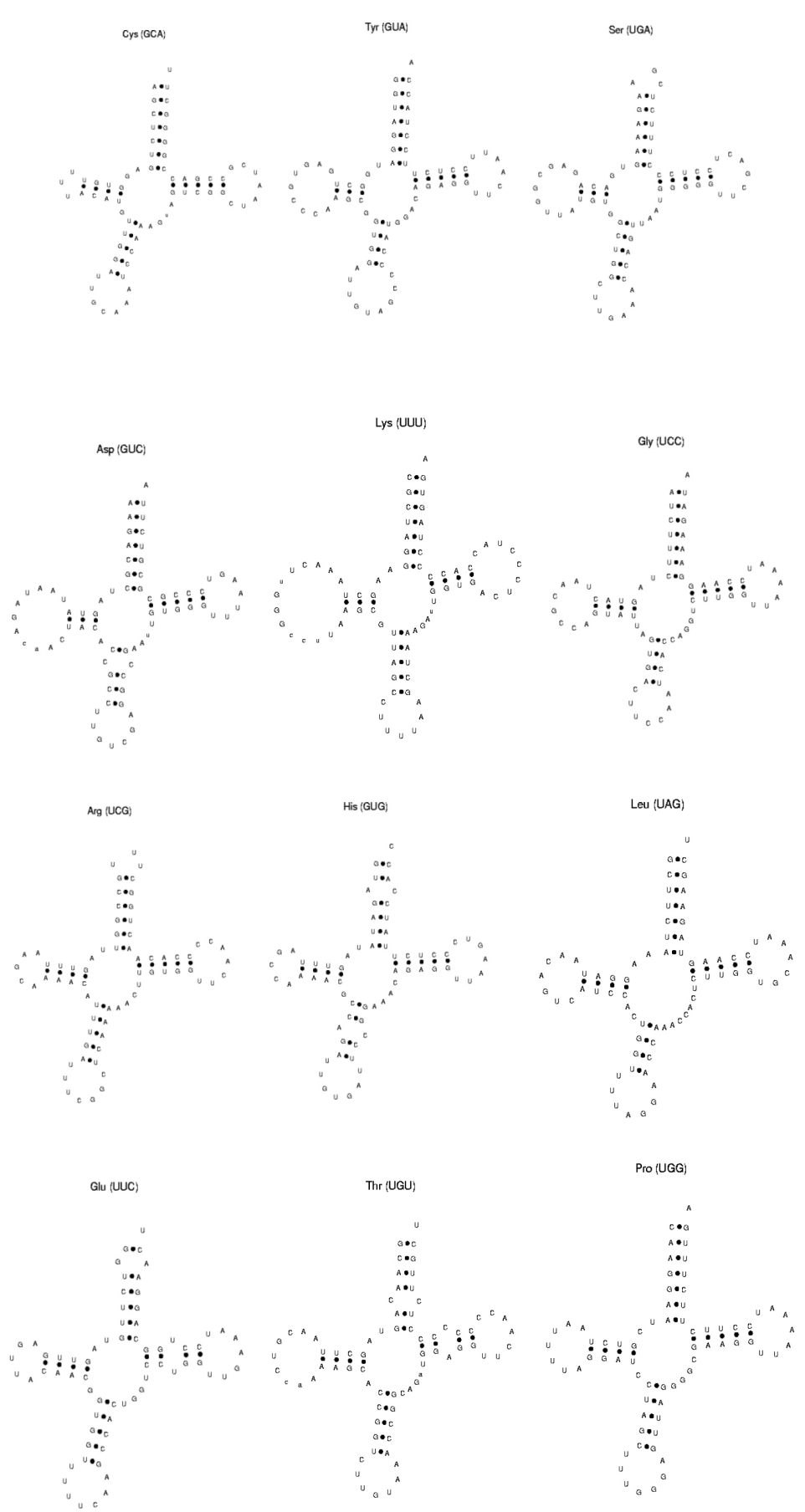

Genetics and Molecular Research 12 (2): 1095-1105 (2013) 
A

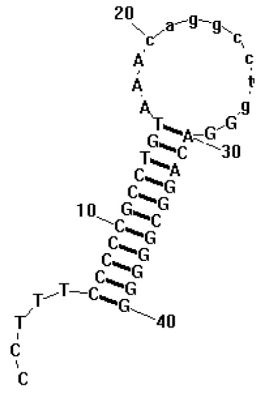

B

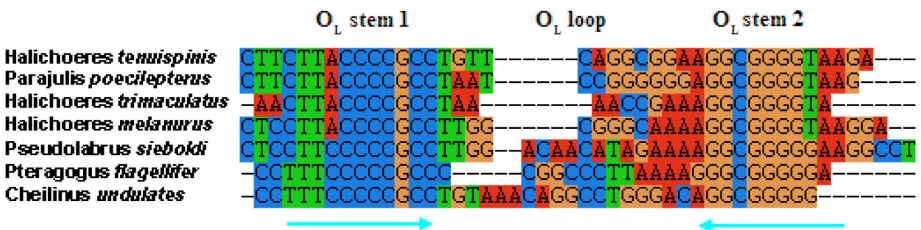

Figure 4. A. Secondary structure at the origin of light-strand replications $\left(\mathrm{O}_{\mathrm{L}}\right)$ of Cheilinus undulatus mitochondrial DNA. B. Alignment of the $\mathrm{O}_{\mathrm{L}}$ stem-loop sequences from 7 species (C. undulatus, Halichoeres melanurus, $H$. tenuispinis, H. trimaculatus, Parajulis poecilepterus, Pseudolabrus sieboldi, and Pteragogus flagellifer) of the family Labridae.

ATCACACAAACGCCCAGCATAATTATGATATCACACGCCTGCCTAATCCACACATTATGC GCTCATGTCTGTGCCCGCAACCCATTATACTAAGCCCACCCAATAAAATGGGGCCACAC ETAS1

A TACATTGCTTGCAGTATTACATATAGCTGACTGCGTGCATACGCCATGGTAATCACCCA GGTATGTGCTTCGACCATTGAACTGCATTGCCCCAGTACCATGACTTAGTACTACCCAC AGCTTAGCAGTACCCGGATGTTAGCGGCGTACCCTTGCGTCCAAGGCGTACAACCAGT CSB-F

GTGTCAAACATTCCACTACACCATGCTAGCCCCCAAGGGCTGGCCGGCGAGAACCTAC CATTACGGTCTATAGACTTGCTAGGTCTTCCTGATATTCAAGGACAGGCTAAGGGAAGC CSB-D

GTCAGAGATACTGATCTATTTCTTGCCTCCGGTTGTTACTTCAGGCTCATTACGGCCGA ACACACCCCTGTCTTTCATCGACGCTTGCATGAATTGATGCTTCGAACACATAATCTTC GTCACCCCGCATGCCAAGCGTTCTCTCCACGGGTGTAAGGGGTTTTTTAGTTTTTTGTA AGTTTGATCCATACTTCAACAGCTCGTGATTCCCAAGTAGTGCCCAAATCTAGGAGAAC TGGCTCGTATCAACGGAAGCAATGAAGAAGACGGGGGTCCGGCAGACCATAAAGGAC CSB-1

TGTCGCTCGCTAGCATTCCACATAAGGATATCGAGTACATACTATAACCTCC GACAGCC CSB-2

CCCCACACCCCCCACTGCTGACAATCGCTTAAGGCCCTAGCAACCAAGAACATAAAGA AAGCTCCCACTAGCTTATCTGCTTGCAGCTATCACGTCATCTATATTACAGTATCTTAATA CSB-3 TTGCAATACTGTAAAAAAC

Figure 5. Complete sequences of the Cheilinus undulatus mtDNA control region. The conserved sequences including extended termination-associated sequences (ETAS), conserved sequence block (CSB), and central domain (CSB-F and CSB-D), are given in boxes. 


\section{ACKNOWLEDGMENTS}

Research supported by the National Natural Science Foundation of China (\#40966003), the National R\&D Program of China (\#2007BAD29B03), the National Science and HighTechnology Program of China (\#2007AA091404), the Youth Science Foundation of Hainan University (\#qnjj 1225), and the Open Foundation of Hainan Key Laboratory of Tropical Hydrobiology Technology (\#shkyjj0801).

\section{REFERENCES}

Boore JL (1999). Animal mitochondrial genomes. Nucleic Acids Res. 27: 1767-1780.

Bourlat SJ, Rota-Stabelli O, Lanfear R and Telford MJ (2009). The mitochondrial genome structure of Xenoturbella bocki (phylum Xenoturbellida) is ancestral within the deuterostomes. BMC Evol. Biol. 9: 107.

Cao J, Liu WD, Ge LL, Gao XG, et al. (2007). Structure of mtDNA control region in variegate flounder verasper variegate. Fish. Sci. 26: 678-681.

Craig MT, Pondella DJ, Franck JP and Hafner JC (2001). On the status of the Serranid fish genus Epinephelus: evidence for paraphyly based upon 16S rDNA sequence. Mol. Phylogenet. Evol. 19: 121-130.

Ding S, Zhuang X, Guo F, Wang J, et al. (2006). Molecular phylogenetic relationships of China Seas groupers based on cytochrome b gene fragment sequences. Sci. China C Life Sci. 49: 235-242.

Hou WR, Chen Y, Wu X, Hu JC, et al. (2007). A complete mitochondrial genome sequence of Asian black bear Sichuan subspecies (Ursus thibetanus mupinensis). Int. J. Biol. Sci. 3: 85-90.

Maggio T, Andaloro F, Hemida F and Arculeo M (2005). A molecular analysis of some Eastern Atlantic grouper from the Epinephelus and Mycteroperca genus. J. Exp. Mar. Biol. Ecol. 321: 83-92.

Miya MM and Nishida (2000). Use of mitogenomic information in teleostean molecular phylogenetics: a tree-based exploration under the maximumparsimony optimality criterion. Mol. Phylogenet. Evol. 17: 437-455.

Ojala D, Montoya J and Attardi G (1981). tRNA punctuation model of RNA processing in human mitochondria. Nature 290: 470-474.

Pereira SL (2000). Mitochondrial genome organization and vertebrate phylogenetics. Genet. Mol. Biol. 23: 745-752.

Sadovy YJ (2002). The Humphead Wrasse - A Threatened Reef Fish. SPC Live Reef Fish Information Bulletin \#10.

Sadovy YJ and Vincent ACJ (2002). Ecological Issues and the Trades in Live Reef Fishes. In: Coral Reef Fishes Dynamics and Diversity in a Complex Ecosystem (Sale PP, ed.). Academic Press, San Diego, 391-420.

Sadovy YJ, Kulbicki M, Labrose P, Letourneur Y, et al. (2003). Humphead wrasse, Cheilinus undulatus: synopsis of a threatened and poorly known giant coral reef fish. Rev. Fish Biol. Fish. 13: 327-364.

Sbisa E, Tanzariello F, Reyes A, Pesole G, et al. (1997). Mammalian mitochondrial D-loop region structural analysis: identification of new conserved sequences and their functional and evolutionary implications. Gene 205: 125-140.

Shadel GS and Clayton DA (1997). Mitochondrial DNA maintenance in vertebrates. Annu. Rev. Biochem. 66: 409-435.

Sheffield NC, Song H, Cameron SL and Whiting MF (2008). A comparative analysis of mitochondrial genomes in Coleoptera (Arthropoda: Insecta) and genome descriptions of six new beetles. Mol. Biol. Evol. 25: 2499-2509.

Tamura K, Dudley J, Nei M and Kumar S (2007). MEGA4: Molecular Evolutionary Genetics Analysis (MEGA) software version 4.0. Mol. Biol. Evol. 24: 1596-1599.

Tan W, Guo YS, Wang ZD and Liu CW (2010). Structure of the mitochondrial DNA control region of snapper species and their phylogenetic relationship. Acta Oceanol. Sin. 32: 139-145.

Tang QY, Liu HZ, Yang XP and Xiong BX (2009). Studies on the structure of the mitochondrial DNA control region and phylogenetic relationships of the subfamily Botiinae. Acta Hydrobiol. Sin. 29: 645-653.

Thompson JD, Gibson TJ, Plewniak F, Jeanmougin F, et al. (1997). The CLUSTAL_X windows interface: flexible strategies for multiple sequence alignment aided by quality analysis tools. Nucleic Acids Res. 25: 4876-4882. 